\title{
フェライトの熱力学
}

\author{
関 根 啓一・山口喬 \\ (慶応義塾大学 工学部 応用化学科) \\ (1979 年 2 月 1 日受付)
}

\section{Thermodynamics of Ferrite Systems}

\author{
Keiichi SEKINE and Takashi YAMAGUCHI \\ (Department of Applied Chemistry, Faculty of Engineering, Keio University, Yokohama-shi 223) \\ [Received February 1, 1979]
}

Key-words : Thermodynamics, Spinel, Ferrite, Phase relation, Solid solution, Activity

1. 緒言

スピネル型フェライト $\mathrm{MFe}_{2} \mathrm{O}_{4}(\mathrm{M}=\mathrm{Mg}, \mathrm{Mn}, \mathrm{Fe}$, $\mathrm{Co}, \mathrm{Ni}, \mathrm{Cu}, \mathrm{Zn}, \mathrm{Cd})$ 及びその固溶体が磁性材料として の地位を確保したのは 1950 年代のことであるが，フェ ライトの基礎研究も盛しに行われ，近年になってようや くフェライトの熱力学値や $\mathrm{M}-\mathrm{Fe}-\mathrm{O} 3$ 元系の化学平衡 に関して，かなりのデータが蓄積されるに至った。

本稿はこれまでの研究を基にして，フェライトの熱力 学值を集成し, $\mathrm{M}-\mathrm{Fe}-\mathrm{O} 3$ 元系の相関係, スピネル固 溶体の性質を考察したものである。

\section{2. フェライトの熱力学}

\section{1 フェライトの熱力学的安定性}

フェライトの高温に抢ける状態は, 温度及び気圈の酸 素分圧によって決まる. $\mathrm{MFe}_{2} \mathrm{O}_{4}$ の解離に伴う相関係に ついては後に詳述するが, 解離の第 1 段階は $\mathrm{Fe}^{8+}$ の一 部の還元によるマグネタイトの生成である、いま各成分 間に固溶体が生成しないと仮定すると, 解離の第 1 段階 は次のようになる.

$$
3 \mathrm{MFe}_{2} \mathrm{O}_{4}=3 \mathrm{MO}+2 \mathrm{Fe}_{3} \mathrm{O}_{4}+1 / 2 \mathrm{O}_{2}
$$

上式から, 平衡酸素圧 $p_{(1)}$ * はフェライトの安定性を 示す尺度となる・ $p_{(1)}$ はフェライトの生成自由エネルギ 一によって決まる。

$$
\begin{aligned}
& \mathrm{MO}+\mathrm{Fe}_{2} \mathrm{O}_{3}=\mathrm{MFe}_{2} \mathrm{O}_{4} \\
& 3 \mathrm{Fe}_{2} \mathrm{O}_{3}=2 \mathrm{Fe}_{3} \mathrm{O}_{4}+1 / 2 \mathrm{O}_{2}
\end{aligned}
$$

(1)〜(3) 式の自由エネルギ一変化をそれぞれ $\Delta G_{1}$, $\Delta G_{2}$ 及び $\Delta G_{\mathrm{f}}$ とすると, $\Delta G_{1}=\Delta G_{2}-3 \Delta G_{\mathrm{f}}$ であるか ら,

* $\mathrm{po}_{2(1)}$ と書くべきであるが, 誤解の抢それのないときは本文 中に限り, 以下 $p_{(1)}$ と書き, 添字の $\mathrm{O}_{2}$ を省略する。

$$
\log p_{(1)}=\log p_{(2)}+1.31 \Delta G_{\mathrm{f}} / T
$$

$\Delta G_{\mathrm{f}}$ は一般に負であるから, $\mathrm{Fe}_{2} \mathrm{O}_{3}$ のマグネタイトー の解離注フェライトの生成によって起こりにくくなる. 各成分間に固溶体を生成するときも同じように扱われ る11.ここに一例をあげたように，ある与えられた温度 と気圈の酸素分圧下で高温におけるフェライトの状態を 知るには, フェライトの生成自由エネルギ一及び固溶体 の熱力学性質を知る必要がある.

\section{2 フェライトの熱力学値の測定方法}

フェライトの熱力学值の測定法としては，(1) 熱量計 を用いる方法，（2）ガス平衡法，（3）起電力法がある. 各方法については, O. Kubaschewskiら²) が詳しくまと めている.

\subsection{1 熱量計を用いる方法}

熱量計を用いた測定としては，スピネル構造を有する 酸化物の生成エンタルピーを溶融酸化物 $9 \mathrm{PbO} \cdot 3 \mathrm{CdO}$. $4 \mathrm{~B}_{2} \mathrm{O}_{3}$ を用いて求めた $\mathrm{Kleppa}^{3)}$ や $\mathrm{Mg}, \mathrm{Mn}, \mathrm{Zn}, \mathrm{Cu}$ フェライト (4) 8) の生成エンタルピーを $\mathrm{H}_{2} \mathrm{SO}_{4}-\mathrm{H}_{3} \mathrm{PO}_{4}$ 溶 液への溶解熱から求めた Khomyakov などの実験結果が ある. Kleppa によれば, 酸に溶けなかったような酸化 物でも, 適当な組成の溶融酸化物を用いると, 速く溶解 するままた，溶媒と溶質の性質が似ているために，熱量 計の溶媒として使われる溶融酸化物中への試料酸化物の 溶解エンタルピーは, 酸を溶媒として用いたときと比較 すると数值的にかなり小さい. したがって溶融酸化物法 による高温熱量測定の精度はよくなっている.このよう な方法において，熱効果が非常に小さいときや，反応が 非常に遅いときなどには，かくはし熱の効果を考慮する 必要がある。

\subsection{2 ガス平衡法}


ガス平衡法には, 試料酸化物を循環する混合ガス $\left(\mathrm{H}_{2} /\right.$ $\mathrm{H}_{2} \mathrm{O}, \mathrm{CO} / \mathrm{CO}_{2}$ など） 子ん囲気内で一定温度に保ち, 平 衡が達成された後に気相と試料の分析を行う方法と, 温 度を連続的に変化させて, 既知の組成の酸化物試料の重 量分析を連続的に行う方法がある.これらの測定におい ては, 試料が完全に平衡状態になっていることを確認し なければならない，試料中の金属成分の揮散がある場合 には，凝縮相の組成の決定がむずかしくなる.

フェライトの熱力学的性質をガス平衡法により測定し た例としては， $\mathrm{CO}_{2} / \mathrm{CO}$ 混合ガスによる $\mathrm{Mg}-\mathrm{Fe}-\mathrm{O}$ 系 ${ }^{9)}$, $\mathrm{Cu}-\mathrm{Fe}-\mathrm{O}$ 系 ${ }^{(0), 11)}, \mathrm{Mn}-\mathrm{Fe}-\mathrm{O}$ 系 ${ }^{12), 13)}$ ，及び $\mathrm{H}_{2} / \mathrm{H}_{2} \mathrm{O}$ 混 合ガスによる $\mathrm{Mg}^{15)}, \mathrm{Mn}^{16)}, \mathrm{Ni}^{17)}, \mathrm{Cu}^{18)}$ 及び $\mathrm{Zn}^{19)}$ フ エライトがある。重量分析法では，小野らによる $\mathrm{Ni}-\mathrm{Fe}$ $\mathrm{O}$ 系 ${ }^{20)}$ ，及び $\mathrm{Mn}-\mathrm{Fe}-\mathrm{O}$ 系 ${ }^{21)}$ についての測定，Muan に よる $\mathrm{Co}_{3} \mathrm{O}_{4}-\mathrm{Mn}_{3} \mathrm{O}_{4}$ 系 ${ }^{22}$ についての測定がある。この方 法で注, 重量変化は酸化・還元による試料中の酸素含有 量の増加・滅少のみによると仮定している. 自由エネル ギー変化活平衡酸素圧から計算される。

\subsection{3 起電力法}

固体電解質を用いた起電力法についてはWagner ${ }^{23)}$ が 詳しく述べている．Tretjakow ${ }^{24), 25) ~}$ は固体電解質を用 いた起電力法によりフェライト相の標準生成自由エネル ギーを測定している. $\mathrm{Fe}_{3} \mathrm{O}_{4}-\mathrm{CoFe}_{2} \mathrm{O}_{4}$ 固溶体については Carter ${ }^{26)}$ の，また， $\mathrm{Fe}_{3} \mathrm{O}_{4}-\mathrm{ZnFe}_{2} \mathrm{O}_{4}$ 固溶体については 片山 ${ }^{27)}$ の研究がある.

一般に，ジルコニア固体電解質を用いた酸素濃淡電池 を構成して起電力を測定しこれれら自由エネルギー変 化を求为る.

\section{3 フェライトの熱力学值とその結晶化学的考察}

フェライトの生成自由エネルギー $\Delta G_{f}$ は， $\Delta H_{298}$, $\Delta S_{298}$ 及び $\Delta c_{\mathrm{p}}$ が分っていれば次式から求めることがで きる。

$$
\begin{aligned}
& \Delta G_{\mathrm{f}}=\Delta H_{\mathrm{T}}-T \Delta S_{\mathrm{T}} \\
& \Delta H_{\mathrm{T}}=\Delta H_{298}+\int_{298}^{T} \Delta c_{\mathrm{P}} \mathrm{d} T \\
& \Delta S_{\mathrm{T}}=\Delta S_{298}+\int_{298}^{T} \frac{\Delta c_{\mathrm{P}}}{T} \mathrm{~d} T
\end{aligned}
$$

一般に，比熱は温度の関数として表される。フェライ

卜，及びフェライト構成酸化物の比熱デー夕を表 $1 ， 2$ に示す. 酸化物からのフェライトの生成反応に抒汀る $\Delta c_{\mathrm{P}}$ は表 1 と 2 の*印のついたデー夕から求め表 3 亿示 した. ある温度に狲て測定された $\Delta G_{\mathrm{f}}, \Delta H_{\mathrm{T}}$ 及び $\Delta S_{\mathrm{T}}$ から求めた $298 \mathrm{~K}$ に扔ける值を表 4 亿示した. 計 算に際しては，測定温度まで比熱データが使用できるむ のと仮定した. 表 4 の*印のデータと比熱データを用い て,フェライト生成反応, $\mathrm{MO}+\mathrm{Fe}_{2} \mathrm{O}_{3}=\mathrm{MFe}_{2} \mathrm{O}_{4}$ の $\Delta H$, $\Delta S$ 及び $\Delta G_{\mathrm{f}}$ を温度の関数として求めたものが，図 1〜 3 である.この反応は固体の付加反応であるから， $\Delta S_{298}$

\begin{tabular}{|c|c|c|c|c|c|c|}
\hline Ferrite & $a$ & $b \cdot 10^{3}$ & $c \cdot 10^{-5}$ & $\begin{array}{c}\text { Temperature } \\
(\mathrm{K})\end{array}$ & \multicolumn{2}{|c|}{ Reference } \\
\hline \multirow{3}{*}{$\mathrm{Fe}_{8} \mathrm{O}_{4}$} & $(43.40$ & 16.80 & -12.88 & $298 \sim 1473$ & 28) & $*$ \\
\hline & 21.88 & 48.2 & - & $298 \sim 900\}$ & \multirow{2}{*}{ 2) } & \\
\hline & 48.00 & - & - & $900 \sim 1800\}$ & & \\
\hline \multirow{2}{*}{$\mathrm{NiFe}_{2} \mathrm{O}_{4}$} & $\{43.01$ & 9.90 & -10.72 & $298 \sim 1473$ & 28) & $*$ \\
\hline & 40.5 & - & - & $500 \sim 1000$ & 2) & \\
\hline \multirow{3}{*}{$\mathrm{CoFe}_{2} \mathrm{O}_{4}$} & 50.80 & 5.047 & -5.874 & $298 \sim 1473$ & 28) & * \\
\hline & 31.5 & 33.8 & - & $400 \sim 770\}$ & \multirow{2}{*}{ 2) } & \\
\hline & 49.0 & - & - & $793 \sim 880\}$ & & \\
\hline \multirow{3}{*}{$\mathrm{ZnFe}_{2} \mathrm{O}_{4}$} & $\int 49.9$ & 24.002 & -27.40 & $298 \sim 1473$ & 28) & * \\
\hline & 34.3 & 13.3 & - & $400 \sim 1000$ & 2) & \\
\hline & 30.81 & 13.90 & - & $298 \sim 1000$ & 29) & \\
\hline \multirow{4}{*}{$\mathrm{MgFe}_{2} \mathrm{O}_{4}$} & 43.3 & 13.7 & -8.98 & $298 \sim 900$ & 30) & $*$ \\
\hline & 21.06 & 49.61 & - & $298 \sim 600$ & \multirow{3}{*}{ 29) } & \\
\hline & 45.41 & - & - & $600 \sim 1000\}$ & & \\
\hline & 25.67 & 13.58 & - & $1000 \sim 1500$ & & \\
\hline $\mathrm{MnFe}_{2} \mathrm{O}_{4}$ & 27.29 & 25.60 & - & $298 \sim 1000$ & 29) & $*$ \\
\hline $\mathrm{CuFe}_{2} \mathrm{O}_{4}$ & 33.01 & 1.363 & -1.443 & $298 \sim 1473$ & 28) & $*$ \\
\hline
\end{tabular}

Table 1. Specific heat of ferrites. $c_{\mathrm{p}}=a+b T+c T^{-2} \mathrm{cal} / \mathrm{mol} \cdot \mathrm{deg}$

Table 2. Specific heat of constituent metal oxides of ferrites.

$c_{\mathrm{p}}=a+b T+c T^{-2} \mathrm{cal} / \mathrm{mol} \cdot \mathrm{deg}$

\begin{tabular}{lcccccc}
\hline Oxide & $a$ & $b \cdot 10^{3}$ & $c \cdot 10^{-5}$ & $\begin{array}{c}\text { Temperature } \\
(\mathrm{K})\end{array}$ & Reference \\
\hline $\mathrm{FeO}$ & 12.38 & 1.62 & -0.38 & $298 \sim 1200$ & $31)$ & $*$ \\
$\mathrm{Fe}_{0.947} \mathrm{O}$ & 11.66 & 2.00 & -0.76 & $298 \sim 1500$ & $2)$ & \\
$\mathrm{CoO}$ & 11.54 & 2.04 & -0.4 & $298 \sim 1800$ & $2)$ & $*$ \\
$\mathrm{ZnO}$ & 11.71 & 1.22 & -2.18 & $298 \sim 1600$ & $31)$ & $*$ \\
$\mathrm{NiO}$ & $\left\{\begin{array}{ccccccc}8.80 & 6.00 & - & 298 \sim 1400 & 31) & * \\
-4.99 & 37.58 & 3.89 & 298 \sim 525 \\
13.88 & - & - & 525 \sim 565 \\
11.18 & 2.02 & - & 565 \sim 1800\end{array}\right\}$ & $2)$ & \\
$\mathrm{CuO}$ & 9.27 & 4.80 & - & $298 \sim 1250$ & $31)$ & $*$ \\
$\mathrm{MgO}$ & 10.18 & 1.74 & -1.48 & $298 \sim 2100$ & $31)$ & $*$ \\
$\mathrm{MnO}$ & 11.11 & 1.94 & -0.88 & $298 \sim 1800$ & $31)$ & $*$ \\
$\mathrm{Fe}_{2} \mathrm{O}_{3}$ & $\left\{\begin{array}{cccccc}23.36 & 17.24 & -3.08 & 298 \sim 1100 & 31) & * \\
23.49 & 18.6 & -3.55 & 298 \sim 950 \\
36.0 & - & - & 950 \sim 1050 \\
31.70 & 1.76 & - & 1050 \sim 1750\end{array}\right\}$ & $2)$ & \\
\hline
\end{tabular}

及び $\Delta c_{\mathrm{p}}$ は小さいと考えられるが，表 3 と 4 を見ると必 ずしも無視できないことが分る.

フェライト生成反応に打いて反応成分の一つである $\mathrm{MO}$ 酸化物は, $\mathrm{ZnO}$ がウルッアイト型, $\mathrm{CuO}$ がひずん だ $\mathrm{NaCl}$ 型であるほか, $\mathrm{MgO}, \mathrm{CoO}, \mathrm{FeO}, \mathrm{MnO}, \mathrm{NiO}$ などは $\mathrm{NaCl}$ 型である. $\mathrm{Mg}^{2+}, \mathrm{Co}^{2+}, \mathrm{Fe}^{2+}, \mathrm{Mn}^{2+}$. は tetrahedral site preference を有している ${ }^{36)}$ が, MO 酸化 物として存在する場合には, octahedral site を占める. これは陽イオン配位数の大きい $\mathrm{NaCl}$ 型構造の方が ウルッァイト型構造よりエネルギ一的に得だからである が， $\mathrm{Zn}^{2+}$ の場合は tetrahedral site preference がかな り強いので, ウルッァイト構造のほうがエネルギー的に 


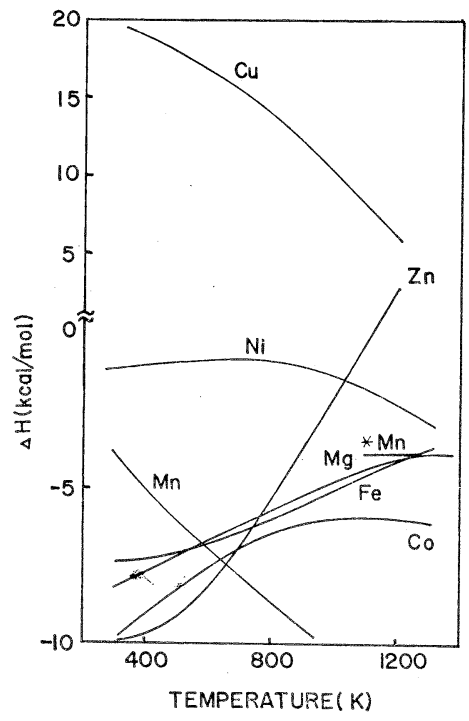

Fig. 1. Standard enthalpy changes for ferrite formation.

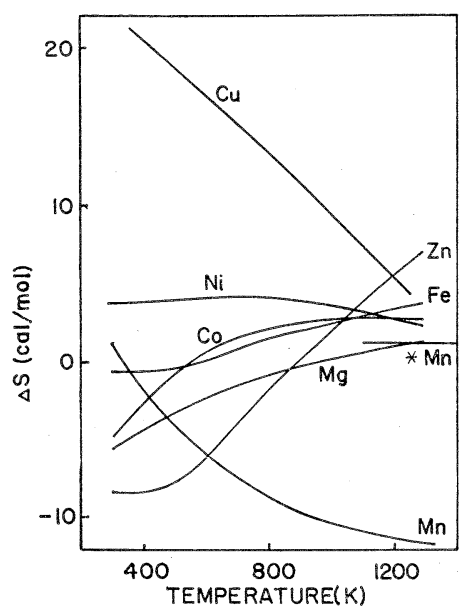

Fig. 2. Standard entropy changes for ferrite formation.

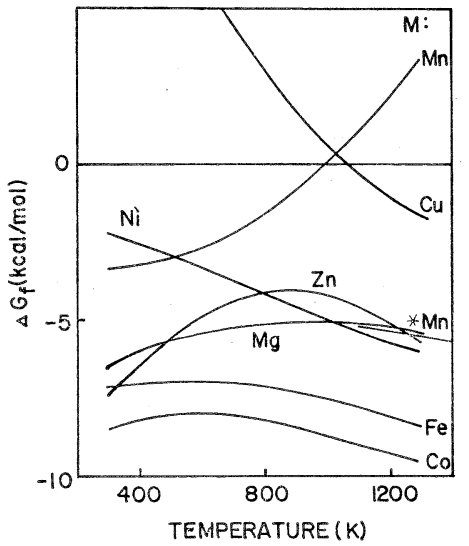

Fig. 3. Standard free energy changes for ferrite formation.
Table 3. $\Delta c_{\mathrm{p}}$ in the ferrite formation $\mathrm{MO}+\mathrm{Fe}_{2} \mathrm{O}_{3}=\mathrm{MFe}_{2} \mathrm{O}_{4}$. $\Delta c_{\mathrm{p}}=a+b T+c T^{-2} \mathrm{cal} / \mathrm{mol} \cdot \mathrm{deg}$

\begin{tabular}{rrccc}
\hline Ferrite & \multicolumn{1}{c}{$a$} & $b \cdot 10^{3}$ & $c \cdot 10^{-5}$ & Temperature $(\mathrm{K})$ \\
\hline $\mathrm{Fe}_{3} \mathrm{O}_{4}$ & 7.66 & -2.06 & -9.42 & $298 \sim 1100$ \\
$\mathrm{NiFe}_{2} \mathrm{O}_{4}$ & 10.85 & +13.34 & -7.64 & $298 \sim 1100$ \\
$\mathrm{CoFe}_{2} \mathrm{O}_{4}$ & 15.90 & -14.23 & -3.19 & $298 \sim 1100$ \\
$\mathrm{ZnFe}_{2} \mathrm{O}_{4}$ & 14.83 & +5.54 & -22.14 & $298 \sim 1100$ \\
$\mathrm{MgFe}_{2} \mathrm{O}_{4}$ & 9.76 & -5.28 & -4.42 & $298 \sim 900$ \\
$\mathrm{MnFe}_{2} \mathrm{O}_{4}$ & -7.18 & +6.42 & +3.96 & $298 \sim 1100$ \\
$\mathrm{CuFe}_{2} \mathrm{O}_{4}$ & 0.38 & -20.68 & +1.64 & $298 \sim 1100$
\end{tabular}

安定となる. また $\mathrm{Ni}^{2+}, \mathrm{Cu}^{2+}$ は octahedral site preference が強い.フェライト生成反応におけるエンタル ピー変化とフェライト構成 2 価イオンの site preference の関係を考えてみた（図 4)。octahedral site preference の強い $\mathrm{Cu}^{2+}, \mathrm{Ni}^{2+}$ では, $\Delta H_{298}$ は正の值で, tetrahedral site preference の強いイオンでは $\Delta H_{298}$ は負の值であ ることが分る。 $\Delta H_{298}$ を決める因子としては，(a) マデ ルングエネルギー，(b)ボルンの反発ポテンシャル，(c) カチオン分布の秩序化エネルギー，(d) site preference energy，（e）陰イオンの分極エネルギー，などがある が，このうちで (d) と（e）が大きな役割を果たしてい るように思われる ${ }^{37)}$. 図4 の結果法，フェライト生成反 応に括いては, $\mathrm{M}^{2+} の$ site preference が特にエンタル ピー変化 $\Delta H$ に影響を及ぼすものと考えられる。图 1 〜3 において, Mn フェライトの挙動が他のフェライト と異なっている.例えば，約 $1000 \mathrm{~K}$ 以上で $\Delta G_{\mathrm{f}}>0$ と なっているが，実際にはそれ以上の温度で $\mathrm{Mn}$ フェラ イトが生成されているのであるから，表 3 の比熱データ から求めた值は実験の結果と合わない，Roshchupkin ${ }^{333}$
Table 4. Standard thermodynamic values for ferrite formation from constituent oxides.

\begin{tabular}{|c|c|c|c|c|c|}
\hline Ferrite & $\begin{array}{l}\Delta G_{298}{ }^{\circ} \\
\mathrm{kcal} / \mathrm{mol}\end{array}$ & $\begin{array}{l}\Delta H_{298^{\circ}} \\
\mathrm{kcal} / \mathrm{mol}\end{array}$ & $\begin{array}{r}\Delta S_{298}{ }^{\circ} \mathrm{cal} / \\
\mathrm{deg} \cdot \mathrm{mol}\end{array}$ & Reference & Method \\
\hline \multirow[t]{2}{*}{$\mathrm{Fe}_{3} \mathrm{O}_{4}$} & -6.1 & -6.0 & -0.21 & 24) & EMF \\
\hline & -7.3 & -7.3 & -0.6 & 3) & $\mathrm{C} *$ \\
\hline \multirow[t]{2}{*}{$\mathrm{CoFe}_{2} \mathrm{O}_{4}$} & -9.0 & -9.3 & -1.2 & 24) & EMF \\
\hline & -8.5 & -9.9 & -4.8 & 3) & $\mathrm{C} *$ \\
\hline \multirow[t]{2}{*}{$\mathrm{NiFe}_{2} \mathrm{O}_{4}$} & -1.5 & -1.5 & +0.1 & 24) & EMF \\
\hline & -2.2 & -1.1 & +3.8 & 3) & $\mathrm{C} *$ \\
\hline \multirow[t]{4}{*}{$\mathrm{MgFe}_{2} \mathrm{O}_{4}$} & -4.5 & -4.8 & +1.1 & 24) & EMF \\
\hline & -3.3 & & & 32) & GE \\
\hline & -6.5 & -8.2 & -5.6 & 3) & C * \\
\hline & & -9.6 & & 5) & $\mathrm{C}$ \\
\hline \multirow[t]{2}{*}{$\mathrm{ZnFe}_{2} \mathrm{O}_{4}$} & -7.4 & -9.9 & -8.3 & 3) & C * \\
\hline & & -5.9 & & 8) & $\mathrm{C}$ \\
\hline \multirow[t]{2}{*}{$\mathrm{MnFe}_{2} \mathrm{O}_{4}$} & -4.2 & -3.9 & +1.2 & 33) & $\mathrm{EMF} *$ \\
\hline & & -3.8 & & 7) & $\mathrm{C}$ \\
\hline \multirow[t]{3}{*}{$\mathrm{CuFe}_{2} \mathrm{O}_{4}$} & & +13.2 & & 3) & C \\
\hline & +12.7 & +19.6 & +23.0 & 34) & $\mathrm{EMF} *$ \\
\hline & & +6.9 & & 6) & $\mathrm{C}$ \\
\hline
\end{tabular}

EMF : Electromotive force, $\mathrm{C}$ : Calorimetry

$\mathrm{GE}$ : Gas equilibrium

は $1100 \sim 1400 \mathrm{~K}$ の範囲で, $\Delta G_{\mathrm{f}}(\mathrm{cal})=-3890-1.2 T$, $\Delta H=-3.9 \mathrm{kcal} / \mathrm{mol}$ 及び $\Delta S=-1.2 \mathrm{cal} / \mathrm{deg} \cdot \mathrm{mol}$ を与 えている.これらの值を図 1 3 に $\mathrm{Mn}^{*}$ で示される直 線で表してある.他の tetrahedral site preference を 有するカチオンから成るフェライトのデータに近い值で あることが分る。な扔図 2 で， $\mathrm{Mg}$ フェライトと $\mathrm{Mn}$ フェライト $\left(\mathrm{Mn}^{*}\right)$ の高温でのエントロピー変化は他の フェライトに比べて小さいが，これはこの二つのフェラ イトのスピネル構造中の二つの格子点位置 $(a$-site と $b$ - 


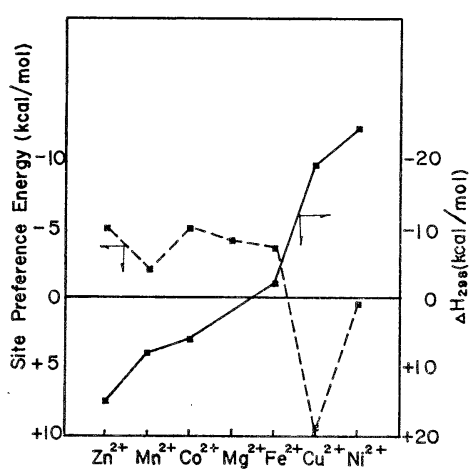

Fig. 4. Site preference energies of ferrite-forming cations.

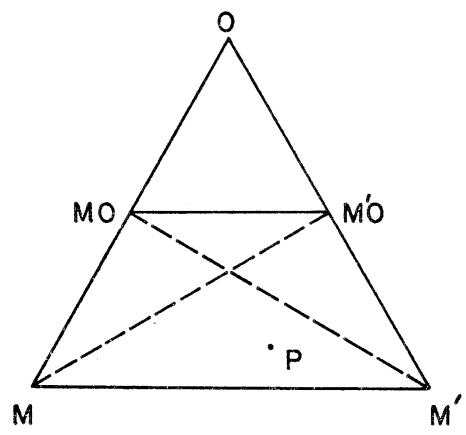

Fig. 5. System $\mathrm{M}-\mathrm{M}^{\prime}-\mathrm{O}$ (schematic).

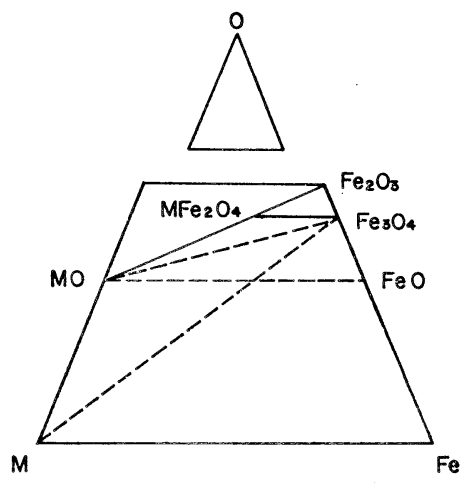

Fig. 6. System $\mathrm{M}-\mathrm{Fe}-\mathrm{O}$. site）への陽イオン分布が温度の影響を受けやすいこと に対応していると思われる. 図 2 に示されているよう に， $\mathrm{Cu}$ フェライトの生成エントロピー変化は大きいが， これは $\mathrm{Cu}^{2+}$ が Jahn-Teller 效果を示すイオンであるた めに生成エントロピーの項に，Jahn-Teller 効果 ${ }^{38}$ によ るエントロピー項が加わるためと思われる ${ }^{34)}$.

図 3 を見ると，低温域では $\mathrm{Cu}$ フェライトの標準生成

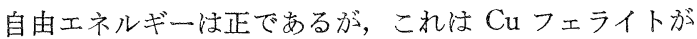
すべての温度で安定であるという多くの実験事実と矛盾 する。これについては現在のところ不明である。

\section{3. フェライトの解離挙動}

\section{$3.1 M-M^{\prime}-0 \quad 3$ 元系}

フェライトの解離によって, どのような相が生成する かは, 図 5 に抢ける $\mathrm{MO}$ と $\mathrm{M}^{\prime} \mathrm{O}$ の相対的な安定性に 依存する。いま， M-M'-O 3 元系においい， $\mathrm{P}$ 組成の ものが， $\mathrm{M}-\mathrm{M}^{\prime}-\mathrm{MO}$ あるいは $\mathrm{M}-\mathrm{M}^{\prime}-\mathrm{M}^{\prime} \mathrm{O}$ のいずれの 3 元系として扱えるか性次の上うにして決めることがで きる ${ }^{399}$.

$$
\mathrm{M}+\mathrm{M}^{\prime} \mathrm{O}=\mathrm{M}^{\prime}+\mathrm{MO}
$$

上の反応の標準自由エネルギ一変化 $\Delta G^{\circ}{ }_{8}$ が負であれば, $\mathrm{M}-\mathrm{M}^{\prime}-\mathrm{MO} 3$ 元系が，また正であれば $\mathrm{M}-\mathrm{M}^{\prime}-\mathrm{MO} 3$ 元系が考えられる.ここで， $\mathrm{MO}$ と $\mathrm{M}^{\prime} \mathrm{O}$ のそれぞれの 解離圧 $p_{\mathrm{MO}}$ と $p_{\mathrm{M}^{\prime} \mathrm{O}}$ は各酸化物の標準生成自由エネル ギーによって与えられるから， $\Delta G_{8}^{\circ}=1 / 2 R T \ln \left(p_{\mathrm{MO}} /\right.$ $p_{\mathrm{M}^{\prime} \mathrm{O}}$ ）となる。したがって図 5 の $\mathrm{P}$ 組成の相構造は $\mathrm{MO}$ と $\mathrm{M}^{\prime} \mathrm{O}$ の相対的な安定性によって決まる. 以上の 考察では, $\mathrm{MO}$ と $\mathrm{M}^{\prime} \mathrm{O}, \mathrm{M}$ と $\mathrm{M}^{\prime}$ の間に固溶体が生成 しないことを仮定している.

次に $\mathrm{MO}$ と $\mathrm{M}^{\prime} \mathrm{O}, \mathrm{M}$ と $\mathrm{M}^{\prime}$ がそれぞれ固溶体を形 成する場合を考えてみる，この場合，自由度は 2 である ので（相の数は固相が 2 , 気相が 1 ) 温度と酸素分圧が 決まれば，互いに平衡にある三つの固溶体の組成は決ま ってくる．（8）式を参照すると，平衡定数 $K_{8}$ は各成
分の活動度 $a$ を用いて次のように与えられる.

$$
K_{8}=\frac{a_{\mathrm{M}^{\prime}} \cdot a_{\mathrm{MO}}}{a_{\mathrm{M}} \cdot a_{\mathrm{M}^{\prime} \mathrm{O}}}
$$

$K$ の值によって，金属と酸化物のそれぞれの固溶体 の組成が決まる*.

\section{2 フェライトの解離挙動}

化学量論組成のフェライト $\left(\mathrm{MFe}_{2} \mathrm{O}_{4}\right)$ の解離による 相構造変化を考えてみる.図6において実線及び破線で 示した 2 元系の端成分が相互溶解しないと仮定すると， フェライト $\mathrm{MFe}_{2} \mathrm{O}_{4}$ の解離の第 1 段階は，マグネタイ トと 2 価金属酸化物の生成である.

$$
3 \mathrm{MFe}_{2} \mathrm{O}_{4}=3 \mathrm{MO}+2 \mathrm{Fe}_{3} \mathrm{O}_{4}+1 / 2 \mathrm{O}_{2}
$$

図6によれば， $\mathrm{MO}-\mathrm{Fe}_{3} \mathrm{O}_{4} 2$ 元系上の 組成に対応す る. 解離の第 2 段階としては, $\mathrm{M}-\mathrm{Fe}_{3} \mathrm{O}_{4} 2$ 元系と $\mathrm{MO}-$ $\mathrm{FeO} 2$ 元系の二つの擬 2 元系が考えられる.このうちい ずれの 2 元系が安定であるか梳次のように決定される。

$\mathrm{M}+1 / 2 \mathrm{O}_{2}=\mathrm{MO}, \Delta G_{11}{ }^{\circ}=1 / 2 R T \ln p_{\mathrm{MO}}$ (11)

$3 \mathrm{FeO}+1 / 2 \mathrm{O}_{2}=\mathrm{Fe}_{3} \mathrm{O}_{4}, \Delta G_{12}{ }^{\circ}=1 / 2 R T \ln p_{\mathrm{Fe}_{3} \mathrm{O}_{4}}$

$$
\left.\begin{array}{l}
\mathrm{M}+\mathrm{Fe}_{3} \mathrm{O}_{4}=\mathrm{MO}+3 \mathrm{FeO} \\
\Delta G_{13}{ }^{\circ}=-R T \ln \left(p_{\mathrm{Fe}_{3} \mathrm{O}} / p_{\mathrm{MO}}\right)
\end{array}\right\}
$$

(13) 式の標準自由エネルギ一変化 $\Delta G_{13}{ }^{\circ}$ が正ならば,

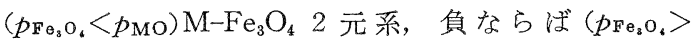
$\left.p_{\mathrm{MO}}\right), \mathrm{M}^{\prime} \mathrm{O}-\mathrm{FeO} 2$ 元系が考えられる.

以上の考察では, $\mathrm{M}-\mathrm{Fe}-\mathrm{Fe}_{3} \mathrm{O}_{4}-\mathrm{MFe}_{2} \mathrm{O}_{4}$ 領域内のす べての 2 元系に扔いて, 端成分が相互溶解しないと仮定 したが，実際にはウスタイト相及びスピネル相がいずれ む固溶体をつくるので，これを考慮する必要がある.こ の場合，解離の第 1 段階は次のように示される.

$$
\begin{aligned}
\mathrm{MFe}_{2} \mathrm{O}_{4} & \rightarrow 3 m \overline{(\mathrm{MO})_{x}(\mathrm{FeO})_{1-x}} \\
& +(1-m) \overline{\left(\mathrm{MFe}_{2} \mathrm{O}_{4}\right)_{X}\left(\mathrm{Fe}_{3} \mathrm{O}_{4}\right)_{1-X}}+m / 2 \mathrm{O}_{2} \\
& \left(X=\frac{1-3 m x}{1-m}, 1-X=\frac{3 m x-m}{1-m}\right) \quad \text { (14) }
\end{aligned}
$$




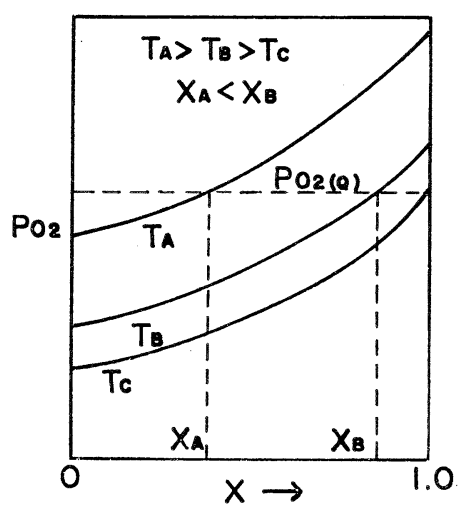

Fig. 7. Equilibrium oxygen pressure as a function of $X$ in $\mathrm{M}_{X} \mathrm{Fe}_{3-X} \mathrm{O}_{4}$.

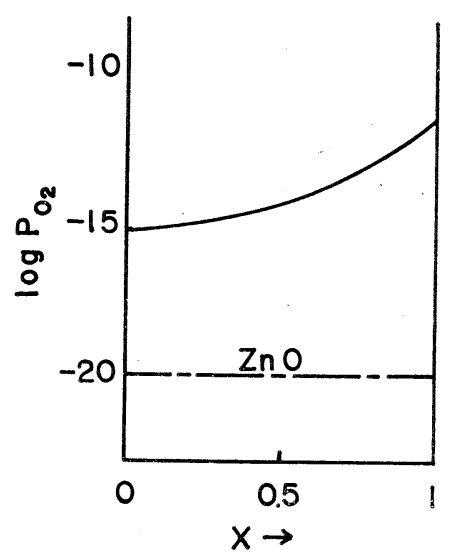

Fig. 8. Equilibrium oxygen pres sure of spinel solid solution $\mathrm{Zn}_{X} \mathrm{Fe}_{3-X} \mathrm{O}_{4}$.

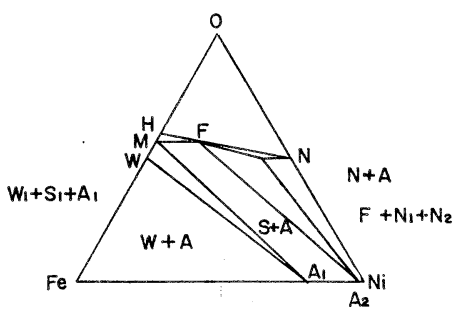

Fig. 9. Phase relations in the system $\mathrm{Fe}-\mathrm{Ni}-\mathrm{O}$ at $1000^{\circ} \mathrm{C}$ in $\operatorname{air}^{40)}$.
スピネル固溶体中のフェライト $\left(\mathrm{MFe}_{2} \mathrm{O}_{4}\right)$ 濃度を表す パラメーター $X$ は, 酸素分圧が一定の場合, フェライ トの種類及び温度によって変化する．スピネル固溶体の 平衡酸素圧の組成依存性は，Tretjakow ${ }^{25)}$ にる実験結 果を参照すると図 7 のようになる。ある酸素分圧 $p o_{2}(Q)$ において温度が $T_{\mathrm{C}}$ 以上になればフェライトは解離しは じめる。そして温度が $T_{\mathrm{B}} \rightarrow T_{\mathrm{A}}$ と高くなると， $X$ の值 は $X_{\mathrm{B}} \rightarrow X_{\mathrm{A}}$ と小さくなる。すなおち, スピネル固溶体 の組成はマグネタイトの組成に接近する. 次に各フェラ イト $\left(\mathrm{MFe}_{2} \mathrm{O}_{4} ; \mathrm{M}=\mathrm{Zn}, \mathrm{Ni}, \mathrm{Mn}, \mathrm{Mg}, \mathrm{Co}, \mathrm{Cu}\right)$ の解 離過程を考えてみる.

\subsection{1 垔鉊フェライト, $\mathrm{ZnFe}_{2} \mathrm{O}_{4}$}

Popov ら ${ }^{19}$ は $\mathrm{H}_{2} / \mathrm{H}_{2} \mathrm{O}$ 混合ガスを用いたガス平衡法に より平衡定数 $K_{\mathrm{p}}$ を測定し, $p_{\mathrm{O}_{2}}=K_{\mathrm{p}} \cdot K_{\mathrm{H}_{2} \mathrm{O}}$ から， スピ ネル固溶体 $\mathrm{Zn}_{x} \mathrm{Fe}_{3-x} \mathrm{O}_{4}(0 \leq x \leq 1)$ が $\mathrm{ZnO}$ と共存する ときの平衡酸素分圧をいろいろの温度で求めた.ここで $K_{\mathrm{p}}$ と $K_{\mathrm{H}_{2} \mathrm{O}}$ はそれぞれ次の反応に対応する.

$$
\left\{\begin{array}{c}
\frac{2}{m} \mathrm{ZnFe}_{2} \mathrm{O}_{4}+2 \mathrm{H}_{2} \\
=6 \mathrm{ZnO}+\frac{2(1-m)}{m} \mathrm{Zn}_{x} \mathrm{Fe}_{3-x} \mathrm{O}_{4}+2 \mathrm{H}_{2} \mathrm{O} \\
(x=(1-3 m) /(1-m)) \\
2 \mathrm{H}_{2} \mathrm{O}=2 \mathrm{H}_{2}+\mathrm{O}_{2}
\end{array}\right.
$$

$900^{\circ} \mathrm{C}$ における平衡酸素圧の組成依存性を図 8 亿示 す. 図中に $\mathrm{ZnO}$ のデータ $\mathrm{FeO}$ をほとんど固溶しないと考えられるので ${ }^{41)}$ ，少な くともこの温度において，組成 $X$ によらず $p_{\mathrm{sp}}>p_{\mathrm{ZnO}}$ である.したがって亜鉛フェライトでは，(11）式にお いて $x$ は $m$ に関係なく $x=1$ となるので次式で表 せる.

$$
\begin{aligned}
& \mathrm{ZnFe}_{2} \mathrm{O}_{4} \rightarrow 3 m \mathrm{ZnO}+(1-m) \mathrm{Zn}_{X} \mathrm{Fe}_{3-X} \mathrm{O}_{4} \\
& +m / 2 \mathrm{O}_{2}\left(X=\frac{1-3 m}{1-m}\right)
\end{aligned}
$$

(15) 式で $0 \leqq m \leqq 1 / 3$ である. 還元率*が $8.3 \%(m=$ 1/3) のときにスピネル相はすべてマグネタイト $\mathrm{Fe}_{3} \mathrm{O}_{4}$ になる. 更に還元が進めば $p_{\mathrm{Fe}_{3} \mathrm{O}}>p_{Z_{\mathrm{n} \mathrm{O}}}$ であるからマ グネタイトが分解して $\mathrm{FeO}$ となる。

\section{2 .2 ニッケルフェライト, $\mathrm{NiFe}_{2} \mathrm{O}_{4}$}

大気中, $1000^{\circ} \mathrm{C}$ に扮ける $\mathrm{Ni}-\mathrm{Fe}-\mathrm{O} 3$ 元系状態図 ${ }^{40)}$ を図 9に示す.このとき，スピネル及び金属相と平衡に 存在する $\mathrm{NiO}$ 中に壮 $13.0 \mathrm{wt} \%$ の $\mathrm{Fe}$ が存在してい る. $1050^{\circ} \mathrm{C}$ では $13.2 \mathrm{wt} \%^{20)}$ というデータが報告され ているが，この場合の解離圧は， $\log p \mathrm{O}_{2}=-9.90$ で与 えられ，純粋な $\mathrm{NiO}$ について求められている解離圧の データ $\log p_{\mathrm{O}_{2}}=-9.63^{23)}$ より小さくなる. しかしフェ ライトと平衡に存在する $\mathrm{NiO}$ はほとんど純粋であるか $ら^{40), 17)}, \mathrm{NiFe}_{2} \mathrm{O}_{4}$ の解離は Chufarov ら ${ }^{17)}$ によれ゙次 のようになる。

$$
\begin{gathered}
\mathrm{NiFe}_{2} \mathrm{O}_{4} \rightarrow(1-m) \mathrm{Ni}^{2+} \frac{1-3 m}{1-m} \mathrm{Fe}^{2+} \frac{2 m}{1-m} . \\
\mathrm{Fe}_{2}{ }^{3+} \mathrm{O}_{4}+3 m \mathrm{NiO}+m / 2 \mathrm{O}_{2}
\end{gathered}
$$

(16) 式が成り立つのは $1000^{\circ} \mathrm{C}$ では還元率 $6.5 \%(\mathrm{~m}$ =0.26）までであり，還元率が $6.5 \%$ から $26 \%$ までは $\mathrm{NiO}$ が解離してスピネル, $\mathrm{NiO}$ 及び $\mathrm{Ni}$ の 3 相が平衡 に存在し，26\% から $43 \%$ まではスピネルと合金の 2 相 が平衡に存在する. 還元率と酸素圧の関係を示したのが 図 10 である. $1050^{\circ} \mathrm{C}$ において, $N_{\mathrm{Ni}} /\left(N_{\mathrm{Ni}}+N_{\mathrm{Fe}}\right)$ と 酸素圧の変化によって相関係がどうなるかを図 1120) に 示す. ニッケルフェライト $\mathrm{NiFe}_{2} \mathrm{O}_{4}$ を還元すると, $\mathrm{A}$ 点 $(-\log p \doteqdot 4)$ から $\mathrm{NiO}$ が解離し始め, $\mathrm{B}$ 点 $(-\log p$ ○10) でスピネル， $\mathrm{NiO}$ 及び合金 3 相共存となる. こ の場合，合金相の組成は純 $\mathrm{Ni} に$ 近いが， $\mathrm{NiO}$ 相は 13.2 at\% の $\mathrm{Fe}$ を含んでいる. スピネル相は $N_{\mathrm{Ni}} /\left(N_{\mathrm{Ni}}+\right.$

*還元率 : フェライトの 含有酸素がすべて 放出されたときを 還元率 100\% としてある. 


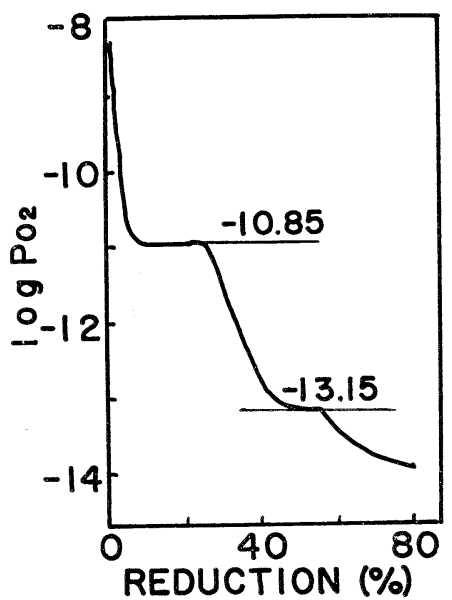

Fig. 10. Relation between equilibrium oxygen pressure and fractional reduction of $\mathrm{NiFe}_{2} \mathrm{O}_{4}$ at $1000^{\circ} \mathrm{C}$.
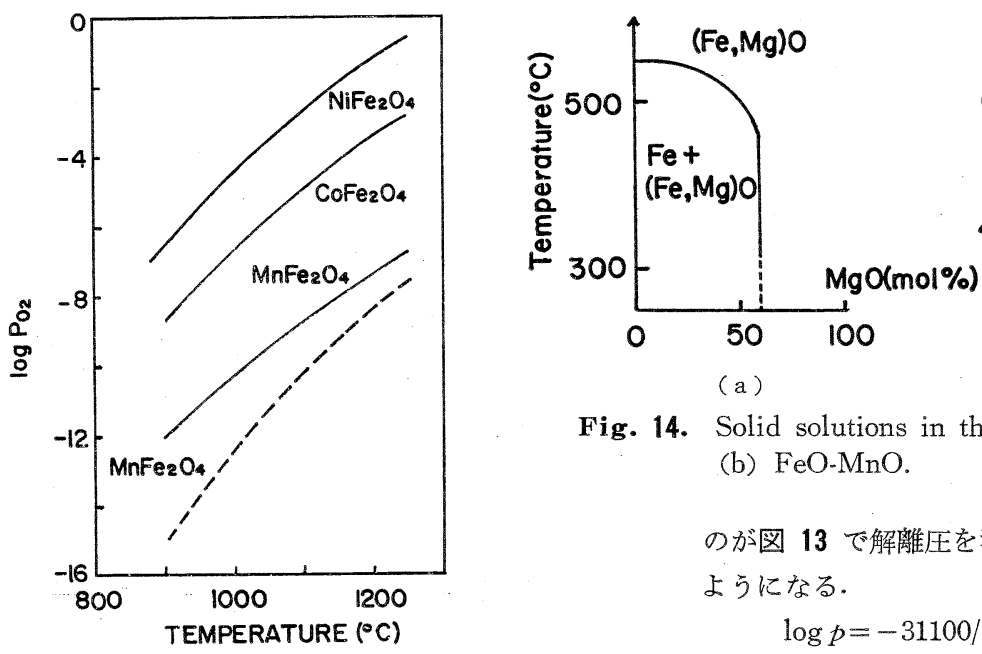

(a) (b) $\mathrm{FeO}-\mathrm{MnO}$. ようになる。

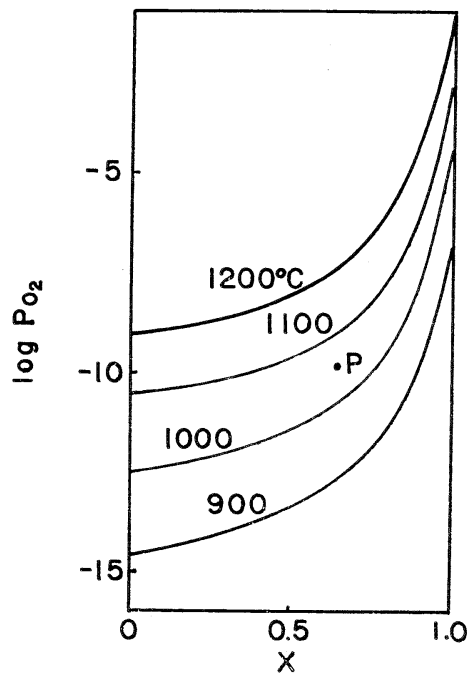

Fig. 12. Equilibrium oxygen pressure of spinel solid solution $\mathrm{Ni}_{X} \mathrm{Fe}_{3-X} \mathrm{O}_{4}$.

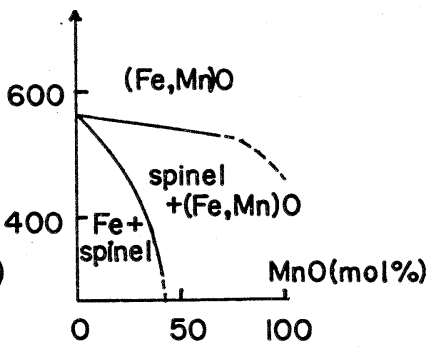

(b)

Fig. 14. Solid solutions in the systems (a) $\mathrm{FeO}-\mathrm{MgO}$,

のが図 13 で解離圧を温度の関数として表すと, 次式の

$$
\log p=-31100 / T+20.0(1173 \sim 1473 \mathrm{~K})
$$
$1050^{\circ} \mathrm{C}$ で $\log p=-3.5,1000^{\circ} \mathrm{C}$ で $\log p=-4.4$ と なり，小野ら ${ }^{20)}$ や Chufarov ら ${ }^{177}$ とる值に近い。

3.2.3 マグネシウム, マンガン, コバルトフェライト $\mathrm{MgO}-\mathrm{FeO}$ 系, $\mathrm{MnO}-\mathrm{FeO}$ 系仙図 14(a), $(\mathbf{b})^{42)}$ で 示されるように高温に㧈いては完全に固溶する。また， $\mathrm{CoO}-\mathrm{FeO}$ 系固溶体はほぼ理想溶液に近い222。 したがっ て解離の第 1 段階は (17) 式で表せる.

$$
\begin{aligned}
& \mathrm{MFe}_{2} \mathrm{O}_{4} \rightarrow 3 m \overline{(\mathrm{MO})_{x}(\mathrm{FeO})_{1-x}} \\
& \quad+(1-m) \overline{\left(\mathrm{MFe}_{2} \mathrm{O}_{4}\right)_{X}\left(\mathrm{Fe}_{3} \mathrm{O}_{4}\right)_{1-X}}+m / 2 \mathrm{O}_{2} \\
& \quad\left(X=\frac{1-3 m x}{1-m}, 1-X=\frac{3 m x-m}{1-m}\right)
\end{aligned}
$$

これらのフェライトでは最初に遊離するウスタイト相 は, $\mathrm{MO}\left(\mathrm{M}=\mathrm{Mg}^{43)}, \mathrm{Mn}^{44)}, \mathrm{Co}^{22)}\right)$ であり, フェライト の還元が進むにつれてウスタイト相中の鉄イオン濃度が 大きくなる．還元率 $25 \%(m=1)$ でスピネル相は消失 
し，その後はウスタイト相から 鉄あるいは合金が遊離 し，ウスタイト相は $\mathrm{MO}$ 組成に近づく.

\subsection{3 a マグネシウムフェライト, $\mathrm{MgFe}_{2} \mathrm{O}_{4}$}

$1300^{\circ} \mathrm{C}$ における $\mathrm{MgO}-\mathrm{FeO}-\mathrm{Fe}_{2} \mathrm{O}_{3} \quad 3$ 元状態図を図 15 に示す ${ }^{45)}$. $1300^{\circ} \mathrm{C}$ において $\mathrm{MgFe}_{2} \mathrm{O}_{4}$ が解離し始め るのは $\log p=-0.68$ のときであり，酸素圧が更に下が るとスピネル相の組成は $\mathrm{Fe}_{3} \mathrm{O}_{4}$ に近づく、咸中に示し た破線は等金属比線で, 酸素の脱離に伴う組成の変化を 示す径路である (dissociation path とも呼ばれる). $\log p$ $=-7$ の場合, 全体の組成は $\mathrm{P}$ になるが, このとき $\mathrm{X}$ 組成のスピネル固溶体とY組成のマグネシオウスタイト が平衡に存在する。更に解離が進むと， $\mathrm{Y}^{\prime}$ 点において

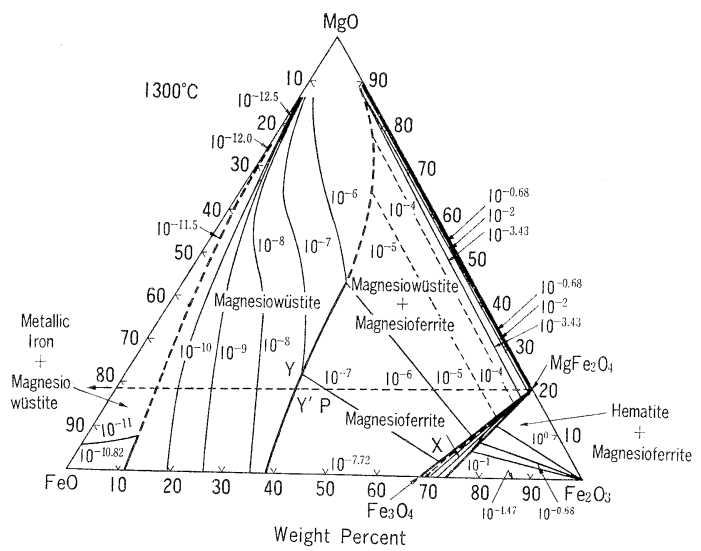

Fig. 15. System $\mathrm{MgO}-\mathrm{FeO}-\mathrm{Fe}_{2} \mathrm{O}_{3}$ at $1300^{\circ} \mathrm{C}$. Heavy and light lines are phase boundaries and oxygen isobars, respectively ${ }^{45)}$.
スピネル相は消滅し， $\mathrm{Y}^{\prime}$ 組成をもつウスタイト相のみ となる. 図 16 は $\mathrm{Mg}_{X} \mathrm{Fe}_{3-X} \mathrm{O}_{4}$ 固溶体の組成 $X$ と平衡 酸素压との関係を示したものである ${ }^{24)} .1100^{\circ} \sim 1200^{\circ} \mathrm{C}$ の温度範囲において， $X=0.9$ のとき $10^{-5.5} \leqq p \leqq 10^{-4}$, $X=0$ のとき $10^{-10.5} \leqq p \leqq 10^{-9}$ となり, Speidel ら ${ }^{45)}$ の 結果と良く一致している.

\subsection{3b マンガンフェライト, $\mathrm{MnFe}_{2} \mathrm{O}_{4}$}

$900^{\circ} \mathrm{C}^{21)}, 1150^{\circ} \mathrm{C}^{46)}, 1300^{\circ} \mathrm{C}^{46)}$ の各温度において, $N_{\mathrm{Mn}} /\left(N_{\mathrm{Mn}}+N_{\mathrm{Fe}}\right)$ と酸素圧の変化によって相関係がど う変わるか子図 17(a)，(b) に示す. $\mathrm{Mn}_{3} \mathrm{O}_{4}$ 注 $\mathrm{Fe}_{3} \mathrm{O}_{4}$

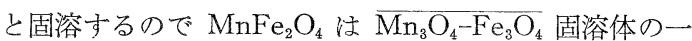
組成であるとも考えられる。図中鎖線はフェライト組成 に対応している. $\mathrm{Mn}_{3} \mathrm{O}_{4}$ の tetragonal-cubic 変態の温 度として $1160^{\circ} \mathrm{C}^{47)}, 1170^{\circ} \mathrm{C}^{48)}$ が得られているが，図 17 (b) で $1150^{\circ} \mathrm{C}$ のとき, $\mathrm{Mn}_{3} \mathrm{O}_{4}$ 組成に近い $(\mathrm{Fe}, \mathrm{Mn}){ }_{3} \mathrm{O}_{4}$ 相の tetragonal-cubic 変態は無視してある. ab で示さ れている領域について， スピネル 固溶体 $\mathrm{Mn}_{C} \mathrm{Fe}_{3-C} \mathrm{O}_{4}$ の解離圧は組成 $C(0 \leqq C \leqq 1)$ の関数として次のように 与えられている。

$$
\log p=1.67 C^{2}+0.33 C-9.85
$$

Averbukh ら ${ }^{44}$ による $900^{\circ} \mathrm{C}$ での還元率と解離压の 関係を図 18 に示す. $\log p \doteqdot-12.5$ からフェライトが 解離し始め, $\log p \div-15$ まではスピネル相とウスタイ 卜相の 2 相となる. 更に $\log p \doteqdot-15$ 加ら $\log p \doteqdot-17$ まではウスタイト相のみ, $\log p \doteqdot-17$ 以下ではウス夕 イト相と合金の 2 相となる.これらの結果は小野ら ${ }^{21}$ に よる報告とほぼ一致している。図 17 から求めた $\mathrm{Mn}$. $\mathrm{Fe}_{2} \mathrm{O}_{4}$ の解離圧の温度依存性を図 13 に示してある. ス

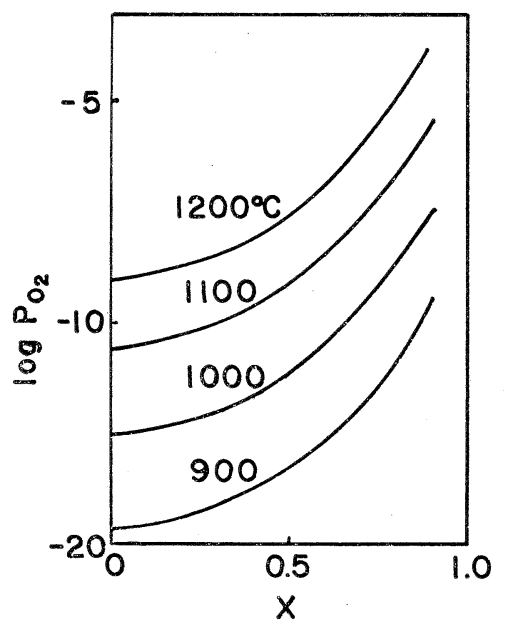

Fig. 16. Equilibrium oxygen pressure of spinel solid solution $\mathrm{Mg}_{X}$. $\mathrm{Fe}_{3-X} \mathrm{O}_{4}$.

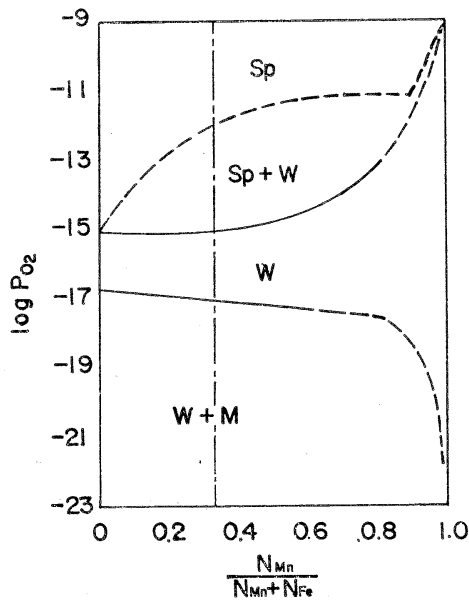

(a)

Fig. 17(a). Phase relations in the system $\mathrm{Mn}$ $\mathrm{Fe}-\mathrm{O}$ at $900^{\circ} \mathrm{C}$.

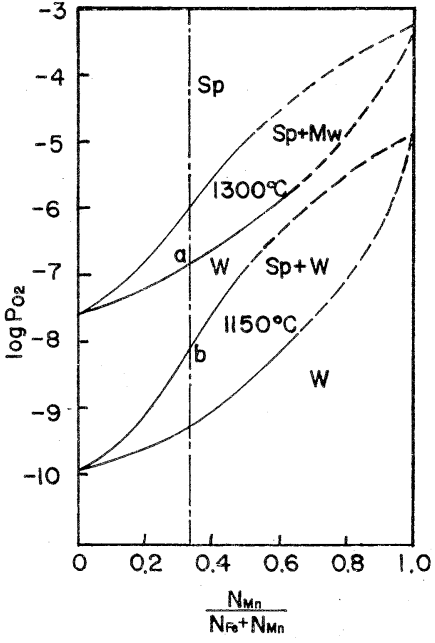

(b)

Fig. 17(b). Phase relations in the system $\mathrm{Mn}$ $\mathrm{Fe}-\mathrm{O}$ at $1150^{\circ}$ and $1300^{\circ} \mathrm{C}$. 


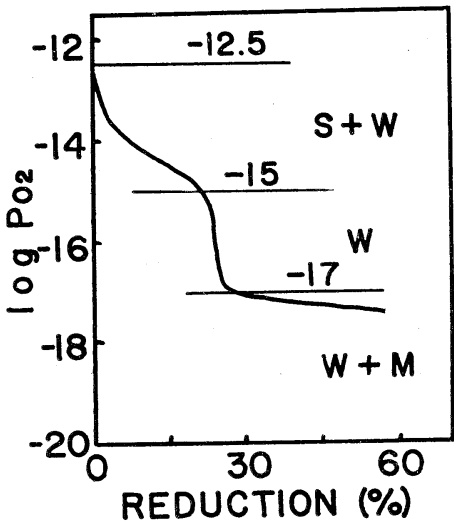

Fig. 18. Relation between equilibrium oxygen pressure and fractional reduction of $\mathrm{MnFe}_{2} \mathrm{O}_{4}$ at $900^{\circ} \mathrm{C}$.

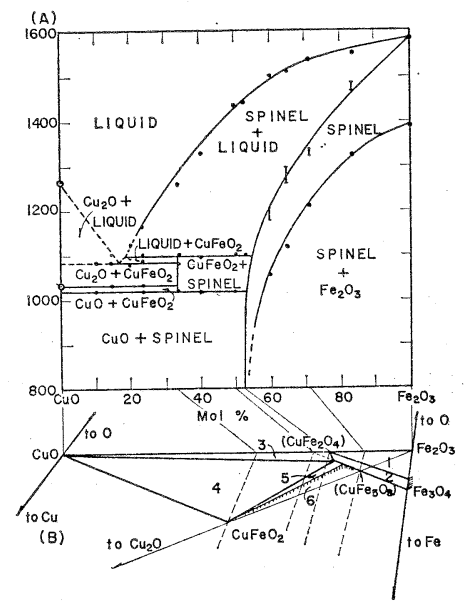

Fig. 21(a). Diagram illustrating phase relations in the system $\mathrm{CuO}-\mathrm{Fe}_{2} \mathrm{O}_{3}$ in air. Dashed lines are constant $\mathrm{Cu} / \mathrm{Fe}$ lines. $1: \mathrm{S}+\mathrm{Fe}_{2} \mathrm{O}_{3}, \quad 2: \mathrm{S}$, $3: \mathrm{S}+\mathrm{CuO}, \quad 4: \mathrm{S}+$ $\mathrm{CuO}+\mathrm{CuFeO}_{2}, 5: \mathrm{S}+$ $\mathrm{CuFeO}_{2}, \quad 6: \mathrm{S}+\mathrm{Liq}$. (S : spinel)

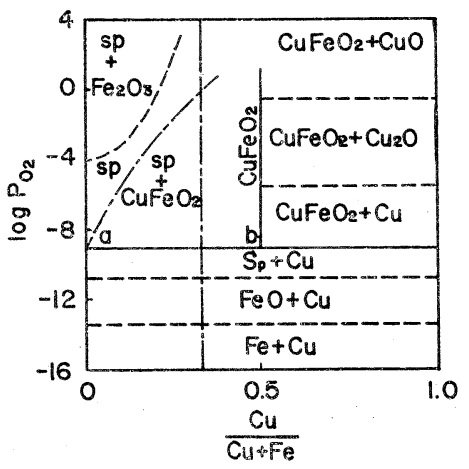

Fig. 21(b). Phase relations in the system $\mathrm{Cu}-\mathrm{Fe}-\mathrm{O}$ at $1100^{\circ} \mathrm{C}$. で与えられる。

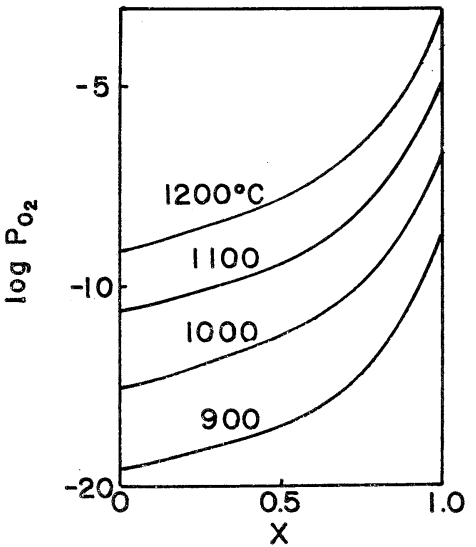

Fig. 20. Equilibrium oxygen pressure of spinel solid solution $\mathrm{Co}_{X} \cdot$ $\mathrm{Fe}_{3-X} \mathrm{O}_{4}$.

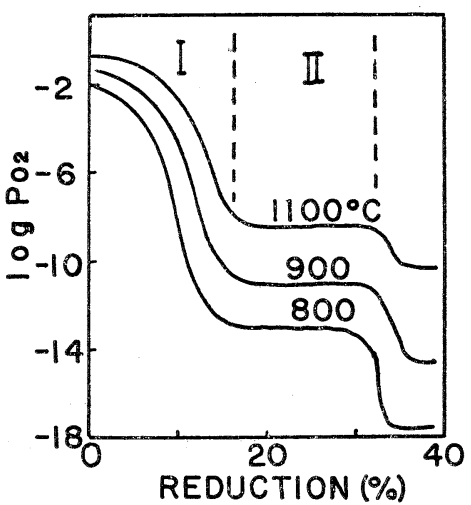

Fig. 22. Relation between equilibrium oxygen pressure and fractional reduction of $\mathrm{CuFe}_{2} \mathrm{O}_{4}$.

ある・マンガンフェライトの場合（図 17） と類似して いることが分る. $\mathrm{Co}_{X} \mathrm{Fe}_{3-X} \mathrm{O}_{4}$ の解離圧の組成依存性 ${ }^{24)}$ を図 20 に示した. この図から求めた $\mathrm{CoFe}_{2} \mathrm{O}_{4}$ の平衡 酸素圧の温度依存性を図 13 に示した。この関係法次式

$$
\log p=-31680 / T+18.2
$$

ニッケル，マンガン及びコバルトフェライトの解離を

ピネルが解離し始める酸素圧 $\left(\log p_{\mathrm{sp}}\right)$, 及びスピネル 相が消滅しウスタイト相のみとなる酸素圧 $\left(\log p_{\mathrm{w}}\right)$ を 温度の関数として表すと次式のようになる.

$$
\begin{aligned}
\log p_{\mathrm{sp}} & =-27780 / T+11.7 \\
\log p_{\mathrm{w}} & =-37840 / T+17.3
\end{aligned}
$$

$3.2 .3 \mathrm{c}$ コバルトフェライト, $\mathrm{CoFe}_{2} \mathrm{O}_{4}$

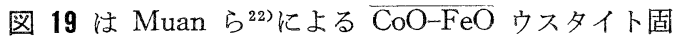
溶体及び $\overline{\mathrm{Co}_{3} \mathrm{O}_{4}-\mathrm{Fe}_{3} \mathrm{O}_{4}}$ スピネル固溶体の平衡状態図で

比較すると，ニッケルフェライトのそれが最も大きく， コバルト，マンガンフェライトの順に減少することが分 る.

\subsection{4 銅フェライト, $\mathrm{CuFe}_{2} \mathrm{O}_{4}$}

図 21(a) $に \mathrm{CuO}-\mathrm{Fe}_{2} \mathrm{O}_{3} 2$ 元系の相関係 ${ }^{49}$ を, また, 図 21 (b) 飞 $\mathrm{Cu}-\mathrm{Fe}-\mathrm{O}$ 系等温状態図 ${ }^{50)}$ を示した。 図中 の鎖線は $\mathrm{CuFe}_{2} \mathrm{O}_{4}$ 組成に対応している. $\mathrm{Cu}-\mathrm{Fe}-\mathrm{O}$ 系 には rhombohedral 構造を持つ化合物 $\mathrm{CuFeO}_{2}$ (delafos- 
site）が存在している。また Zalazinskii ${ }^{51)}$ は， $1000^{\circ} \mathrm{C}$ における $\mathrm{Cu}-\mathrm{Fe}-\mathrm{O}$ 系状態図を説明する際に, 次のよう な解離過程を考えた.

$$
\begin{aligned}
& \mathrm{CuFe}_{2} \mathrm{O}_{4} \rightarrow(1-m)\left[\left(\mathrm{CuFe}_{2} \mathrm{O}_{4}\right) \frac{2 m}{1-m} \cdot\right. \\
& \left.\left(\mathrm{Cu}_{0.5}{ }^{+} \mathrm{Fe}_{2.5}{ }^{3+} \mathrm{O}_{4}\right) \frac{m}{1-m}\right]+1.5 m \mathrm{CuFeO}_{2}+m / 2 \mathrm{O}_{2}
\end{aligned}
$$

$$
\mathrm{Cu}_{0.5} \mathrm{Fe}_{2.5} \mathrm{O}_{4} \rightarrow\left(1-m^{\prime}\right)\left[\left(\mathrm{Cu}_{0.5} \mathrm{Fe}_{2.5} \mathrm{O}_{4}\right) \frac{1-3 m^{\prime}}{1-m^{\prime}}\right. \text {. }
$$$$
\left.\left(\mathrm{Fe}_{3} \mathrm{O}_{4}\right) \frac{2 m^{\prime}}{1-m^{\prime}}\right]+1.5 m^{\prime} \mathrm{CuFeO}_{2}+m^{\prime} / 2 \mathrm{O}_{2}
$$

このように, $\overline{\mathrm{CuFe}_{2} \mathrm{O}_{4}-\mathrm{Fe}_{3} \mathrm{O}_{4}}$ スピネル固溶体は $\mathrm{Cu}_{0.5}$. $\mathrm{Fe}_{2.5} \mathrm{O}_{4}$ と $\mathrm{CuFe}_{2} \mathrm{O}_{4}$ あるいは $\mathrm{Fe}_{3} \mathrm{O}_{4}$ との二つの固溶体 として考えられる。

銅フェライト $\mathrm{CuFe}_{2} \mathrm{O}_{4}$ の解離圧 ${ }^{18)}$ を図 22 亿示す. I の領域ではスピネル相と $\mathrm{CuFeO}_{2}$ が共存し, II の領 域では $\mathrm{CuFeO}_{2}, \mathrm{Cu}, \mathrm{Fe}_{3} \mathrm{O}_{4}$ の 3 相平衡となる. 図 21 (b) で直線 $\mathrm{ab}$ に対応する. また $\mathrm{CuFe}_{2} \mathrm{O}_{4}$ の平衡酸素 圧は, $800^{\circ} \sim 1100^{\circ} \mathrm{C}$ において $10^{-2} \sim 10^{-0.6} \mathrm{~atm}$ という ように他のフェライトに比べて大きく, $\mathrm{Cu}$ フェライト が不安定であることが分る。

\section{3 フェライト系固溶体の活動度}

フェライト系に挍いて固溶体の熱力学的性質を考光る 場合，一般に各成分の活動度 (activity) は必ずしも濃度 に等しくないので，スピネル固溶体，ウスタイト固溶体 の活動度についてのデータを知る必要がある。

ウスタイト固溶体については $\mathrm{FeO}-\mathrm{MgO}$ 系 ${ }^{9), 52)}, \mathrm{FeO}$ $-\mathrm{MnO}$ 系 $^{21,46)}, \mathrm{FeO}-\mathrm{NiO}$ 系及び $\mathrm{FeO}-\mathrm{CoO}$ 系 ${ }^{22)}$ のデー タが報告されている。これらの系においてウスタイト中 の $\mathrm{FeO}$ あるいは $\mathrm{MO}$ の活動度は，Raoult の法則より 正に偏いしている. スピネル固溶体については $\mathrm{Fe}_{3} \mathrm{O}_{4}-$ $\mathrm{ZnFe}_{2} \mathrm{O}_{4}$ 系 $^{27)}, \mathrm{Fe}_{3} \mathrm{O}_{4}-\mathrm{NiFe}_{2} \mathrm{O}_{4}$ 系 ${ }^{17)}, \mathrm{Fe}_{3} \mathrm{O}_{4}-\mathrm{MnFe}_{2} \mathrm{O}_{4}$ 系 ${ }^{53) \text {,54) }}, \mathrm{Fe}_{3} \mathrm{O}_{4}-\mathrm{CuFe}_{2} \mathrm{O}_{4}$ 系 $^{34), 53)}, \mathrm{Fe}_{3} \mathrm{O}_{4}-\mathrm{Co}_{3} \mathrm{O}_{4}$ 系 ${ }^{22)}$ 及
び $\mathrm{NiFe}_{2} \mathrm{O}_{4}-\mathrm{ZnFe}_{2} \mathrm{O}_{4}$ 系 ${ }^{55)}$ のデータが報告されている.

片山ら ${ }^{27)} \mathrm{Fe}_{3} \mathrm{O}_{4}-\mathrm{ZnFe}_{2} \mathrm{O}_{4}$ スピネル固溶体が $\mathrm{Fe}_{2} \mathrm{O}_{3}$ と共存することを利用して，ジルコニア固体電解質を用 いた起電力法により活動度を求めた. 起電力 $E$ を測定 すると次式から, ある温度 $T$ におけるスピネル固溶体 中の $\mathrm{Fe}_{3} \mathrm{O}_{4}$ の活動度が計算できる. いま $\mathrm{Fe}_{3} \mathrm{O}_{4}$ を $\mathrm{A}$, $\mathrm{ZnFe}_{2} \mathrm{O}_{4}$ を $\mathrm{B}$ とすると, Gibbs-Duhem の関係式を参 照して,

$$
\Delta \bar{G}_{\mathrm{A}}=-E F=R T \ln a_{\mathrm{A}}
$$

更に, $\mathrm{ZnFe}_{2} \mathrm{O}_{4}$ の活動度は次式を用いて計算する ${ }^{56)}$.

$$
\ln a_{\mathrm{B}}=\ln X_{\mathrm{B}}-X_{\mathrm{A}} \cdot X_{\mathrm{B}} \alpha_{\mathrm{A}}+\int_{0}^{X_{\mathrm{A}}} \alpha_{\mathrm{A}} \mathrm{d} X_{\mathrm{A}}
$$

ここで $\alpha$ は次式で与えられる.

$$
\alpha_{\mathrm{A}}=\left(\ln \gamma_{\mathrm{A}}\right) /\left(1-X_{\mathrm{A}}\right)^{2}
$$

$X$ 及び $\gamma$ はそれぞれモル分率及び活動度係数である。 (23-a, b) 式によって求めた活動度曲線を図 23 に示す. $\mathrm{Fe}_{3} \mathrm{O}_{4}$ の活動度が $\mathrm{ZnFe}_{2} \mathrm{O}_{4}$ の高濃度側で Raoul九 の法 則からわずかに正に偏いしていることが分る.

Jacob ら ${ }^{34)}$ は， $\mathrm{Fe}_{3} \mathrm{O}_{4}-\mathrm{CuFe}_{2} \mathrm{O}_{4}$ スピネル固溶体にお いて, $\mathrm{CuFe}_{2} \mathrm{O}_{4}$ 側の組成について, マノメータ一あるい はマクレオードゲージを用いて平衡酸素圧を測定した結 果と, $\mathrm{Fe}_{3} \mathrm{O}_{4}$ 側の組成について起電力の測定結果からそ れぞれ活動度を求めた。結果を図 24 に示す. 活動度曲 線はともに Raoult の法則から負に大きく偏いしてい る.これは，構成成分間で化合物をつくりやすいという ことを示している. 実際, $\mathrm{CuFe}_{2} \mathrm{O}_{4} / \mathrm{Fe}_{3} \mathrm{O}_{4}=1 / 1$ の組成 のスピネル相は $\mathrm{CuFe}_{2} \mathrm{O}_{4}$ と $\mathrm{Fe}_{3} \mathrm{O}_{4}$ の固溶体ではない ことが，異常に大きい格子定数や異常に低いキュリ一点 などから支持されている49),51).

$\mathrm{Fe}_{3} \mathrm{O}_{4}-\mathrm{MnFe}_{2} \mathrm{O}_{4}$ 系では図 2553) に示してあるように， $\mathrm{Fe}_{3} \mathrm{O}_{4}-\mathrm{CuFe}_{2} \mathrm{O}_{4}$ 系の場合と違い Raoult の法則より正に 大きく偏いしている.

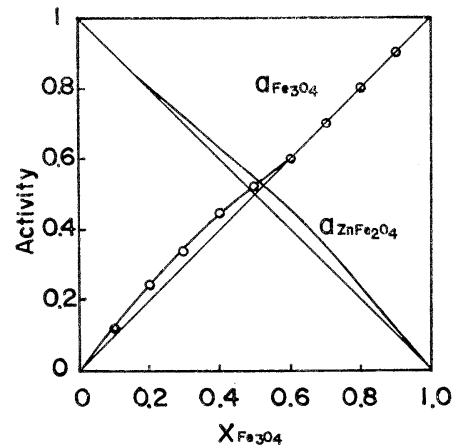

Fig. 23. Activity-composition curves in the system $\mathrm{ZnFe}_{2} \mathrm{O}_{4}-\mathrm{Fe}_{3} \mathrm{O}_{4}\left(900^{\circ} \mathrm{C}\right)$.

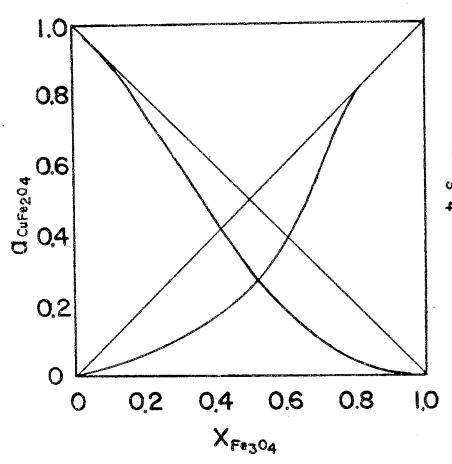

Fig. 24. Activity-composition curves in the system $\mathrm{CuFe}_{2} \mathrm{O}_{4}-\mathrm{Fe}_{3} \mathrm{O}_{4}(1000$ ${ }^{\circ} \mathrm{C}$ ).

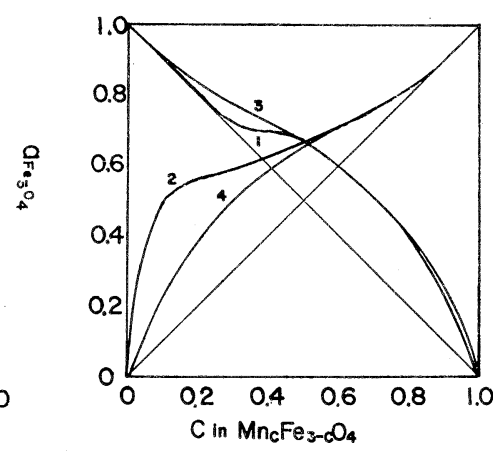

Fig. 25. Activity-composition curves in the system $\mathrm{MnFe}_{2} \mathrm{O}_{4}-\mathrm{Fe}_{8} \mathrm{O}_{4}$ at $900^{\circ} \mathrm{C}$. 1, $3: a_{\mathrm{Fe}_{2} \mathrm{O}_{4}}$, $2,4: a_{\mathrm{MnFe}_{3} \mathrm{O}_{*}}$. 


\section{4. あとがき}

一連のスピネル型フェライトの熱力学的性質や相平衡 は非金属系複合化合物としては最も整備されており，こ れらの結果を基にして更に他の系への抬張や予測が可能 になるものと思われる. なお紙数の関係でフェライト系 平衡状態図に関しては詳述しなかったがこれについては 既に参考文献 1 に述べた.

\section{文献}

1）山口, “新しい工業材料, 第 1 集”, 金原出版 (1963) p. 206.

2) O. Kubaschewski, E. Ll. Evans and C.B. Alcock, "Metallurgical Thermochemistry", Pergamon Press (1967).

3) A. Navrotsky and O.J. Kleppa, J. Inorg. Nucl. Chem., 30, 479 (1968).

4) L.A. Reznitskii and K.G. Khomyakov, Vestn. Mosk. Univ., Ser II, Khim., 15 (1) 41 (1960).

5) L.A. Reznitskii and K.G. Khomyakov, ibid., 15 (2) 28 (1960).

6) L.A. Reznitskii and K.G. Khomyakov, ibid., 15 (4) 40 (1960).

7) L.A. Reznitskii and K.G. Khomyakov, ibid., 15 (6) 24 (1960).

8) L.A. Reznitskii and K.G. Khomyakov, Dokl. Akad. Nauk SSSR, 3, 325 (1960).

9) N.G. Schmahl, B. Frisch and G. Stock, Arch. Eisen. hüttenwes., 32, 297 (1961).

10) H. Dillenburg, Dissertation, Univ. Saarbrücken 1967.

11) N.G. Schmahl, Arch. Eisenhüttenwes., 35, 527 (1964).

12) W. Ringsdorf, Dissertation, Univ. Saarbrücken, 1964.

13) N.G. Schmahl, Dissertation, Univ. Saarbrücken, 1967.

14) I.Ali. Khan, Dissertation, T.H. Aachen, 1960.

15) A.A. Shchepetkin, Dokl. Akad. Nauk SSSR, 152, 124 (1963).

16) B.D. Averbukh, Zh. Fiz. Khim, 36, 2436 (1962).

17) M.T. Kushko, V.F. Balakirev, R.Yu. Dobrovinskii, G.M. Popov, A.N. Men and G.I. Chufarov, Zh. Fiz. Khim., 43, 3095 (1969).

18) A.A. Shchepetkin, M.G. Zhuravleva, G.I. Chufarov, N.M. Stafeeva, V.N. Bogoslovskii, Dokl. Akad. Nauk SSSR, 146, 874 (1962).

19) G.P. Popov, M.I. Simonova, T.A. Ugolnikova, G.I. Chufarov, ibid., 148, 357 (1963).

20）小野, 横川, 山口, 森川, 日本金属学会誌, 35, 750 (1971).

21）小野, 横川, 山口, 森川, ibid., 35, 757 (1971).

22) E. Aukrust and A. Muan, Trans. Metal. Soc. AIME, 230, 1395 (1964).

23) K. Kiukkola and C. Wagner, J. Electrochem. Soc., 104, 379 (1957).

24) J.D. Tretjakow and H. Schmalzried, Ber. Bunsengesellschaft, 69, 396 (1965).

25) J.D. Tretjakow and H. Schmalzried, ibid., 70, 180 (1966).

26) R.E. Carter, J. Am. Ceram. Soc., 43, 448 (1960).
27）片山，柴田，青术，幸塚，日本金属学会誌，40，932 (1976).

28) G.P. Popov, Mater. Nauk Konf. Sovnarkhoz. Nizhnevolzh. Ekon. Raiona. Volgograd. Politech. Inst., 2, 236 (1965).

29) Landolt-Börnstein., 6 Auflage, 4 Teil, (1961).

30) L.A. Reznitskii, K.G. Khomyakov, N.G. Korzhukov and S.E. Orel, Zh. Fiz. Khim, 43, 2165 (1969).

31）吾妻, “冶金物理化学々製錬基礎論”, 朝倉書店 (1962).

32) O. Wever, Dissertation, T.H. Aachen, 1955.

33) V.I. Roshchupkin and V.I. Labrentev, Izv. A.H., Neorg. Mater., 3 (3) 551 (1967).

34) K.T. Jacob, K. Fitzner and C.B. Alcock, Metal. Trans. B., 8, 451 (1977).

35) H. Schmalzried, "Solid State Reactions", Academic Press Inc. (1974).

36) A. Navrotsky and O.J. Kleppa, J. Inorg. Nucl. Chem., 29, 2701 (1967).

37) 中平, “結晶化学”, 講談社 (1977) p. 163.

38) H.A. Jahn and E. Teller, Porc. Roy. Soc., A 161. 220 (1937).

39) B.A. Sidebottom and J. White, Trans. Brit. Ceram. Soc., 60, 96 (1961).

40) A.D. Dalvi and W.W. Smeltzer, J. Electrochem. Soc., 117, 1431 (1970).

41) T. Yamaguchi, Sci. Papers I.P.C.R., 53, 207 (1959).

42) J. Aubry, A. Berthet, R. Duchene, H. Étienne, O. Evrard, F. Jeannot, C. Gleitzer, C. Offroy and P. Perrot, Ann. Chim., 5, 299 (1970).

43) A.A. Shchepetkin, Dokl. Akad. Nauk SSSR, 152, 124 (1963).

44) B.D. Averbukh, Zh. Fiz. Khim., 36, 2436 (1962).

45) D.H. Speidel, J. Am. Ceram. Soc., 50, 243 (1967).

46) K. Schwerdtfeger and A. Muan, Trans. Metal. Soc. AIME., 239, 1114 (1967).

47) H.J. von Hook, Am. Mineral., 43, 69 (1958).

48) G. Meyer, Dissertation, T.H. Aachen, 1957.

49）山口, 窵協, 75, 1 (1967).

50) G.I. Chufarov, Boprosy radioelektroniki., 6, 16(1962).

51) A.G. Zalazinskii, Zh. Fiz. Khim., 43, 1636 (1969).

52) A.B. Shashkina, ibid., 27, 399 (1953).

53) V.N. Bogoslovskii, M.G. Khuravleva, A.N. Men, B.D. Averbukh, N.M. Smafeeva and G.I. Chufarov, Zh. Fiz. Khim., 40, 3000 (1966).

54) T.D. Takenov, B.D. Aberbukh, B.F. Balakirev and G.I. Chufarov, Izv. A.H., Neorg. Mater., 3, 557 (1967).

55) L.A. Bashkirov and M.G. Bashkirova, ibid., 11, 295 (1975).

56) L.S. Darken and R.W. Gurry, "Physical Chemistry of Metals”, McGraw-Hill (1953) p. 264.

\section{参考 文 献}

1) 武井, “フェライトの理論と応用”, 丸善 (1960).

2) 山口, 粉体および粉末治金, 15, 341 (1968).

3) Г.И. Чуфарова и. А.Н. Меня, ТЕРМОДИНАМИКА ПРОЦЕССОВ ВОССТАНОВЛЕНИЯ ОКИСЛОВ МЕТОЛЛОВ, МЕТАЛЛЧРГИЯ, МОСКВА (1970).

4) G.I. Chufarov, Russ. J. Inorg. Chem., 17, 792(1972). 